had a blood urea level above $6.6 \mathrm{mmol} / 1(40 \mathrm{mg} / 100 \mathrm{ml})$ and could be said to have a more than mild degree of renal impairment. The important renal factor in this study was renal tubular dysfunction, as shown by changes in the plasma urate levels. The hyperuricaemia of pre-eclampsia is due to diminished renal tubular excretion and not to excessive production (Chesley and Williams, 1945), and possibly this is due to lactic acidosis caused by anaerobic metabolism in the placenta (Handler, 1960). How prolactin and uric acid metabolism may be linked has yet to be determined, but the possibility that the link is a direct one, in that prolactin may control or modulate uric acid metabolism or excretion during pregnancy, should be considered.

Alternatively, pre-eclampsia may in some way interfere with prolactin clearance. If prolactin is cleared by the kidney, as are some other peptide hormones, then the early involvement of the kidn $2 y$ in pre-eclampsia as measured by plasma urate changes may also indicate a reduced prolactin clearance. Growth hormone $(\mathrm{GH})$, however, which is structurally closely similar to prolactin, is thought to be cleared by the liver, at least in nonpregnant people (Taylor et al., 1972); and the liver is not known to be involved in the early development of pre-eclampsia.

Of the other endocrine changes in pre-eclampsia the reduction in circulating plasma oestrogens (Masson, 1973) provides no explanation of the increased prolactin levels, since plasma oestrogens potentiate prolactin release (Frantz et al., 1972). Human placental lactogen may also be reduced in preeclampsia (Letchworth and Chard, 1972) but its relation to prolactin is not known. The levels of adrenocorticotrophic hormone (ACTH) and thyroid-stimulating hormone (TSH), thought to be of pituitary and not placental origin, are raised in pre-eclampsia (Genazzani et al., 1971; Mukherjee and Swyer, 1972). The same may be true of $\mathrm{GH}$, but this is less certain because of the difficulty of its measurement in pregnancy (Laron et al., 1967). That prolactin is also increased gives further evidence that anterior pituitary function may be generally disturbed in pre-eclampsia. TSH and prolactin are both secreted in response to thyrotrophin-releasing hormone (Bowers et al., 1971), and the release of GH and ACTH are also under hypothalamic control. The results suggest that hypothalamic function could be disturbed in pre-eclampsia, and this seems the most likely explanation of these observations.

Financial aid was given by Merck, Sharp and Dohme Ltd.

We wish to thank the consultant staff of the John Radcliffe Hospital for permission to study their patients, and the staff of the Nuffield Department of Clinical Biochemistry at the Radcliffe Infirmary who did the plasma urate assays. Expert clinical help was given by Miss A. Hewitt, Mrs. V. Calder, Mrs. R. Higson, Miss R. Pangbourne, and Mrs. P. Vaughton. Standard human prolactin was kindly provided by Dr. H. Friesen.

\section{References}

Beilin, L. J., Redman, C. W. G., and Bonnar, J. (1974). In Tenth Symposium On Advanced Medicine, ed. J. G. G. Ledingham, p.1. London, Pitman Medical.

Bowers, C. Y., et al. (1971). Biochemical and Biophysical Research Communication, 45, 1033.

Brown, R. D., Strott, C. A., and Liddle, G. W. (1972). Fournal of Clinical Endocrinology and Metabolism, 35, 736 .

Buckman, M. T., and Peake, G. T. (1973). Science, 181, 755.

Butler, N. R., and Bonham, D. G. (1963). Pertinal Morality: First Report of British Perinatal Mortality Survey. Edinburgh, Livingstone.

Chesley, L. C., and Williams, L. O. (1945). American fournal of Obstetrics and Gynecology, 50,367.

Ensor, D. M., and Ball, J. N. (1972). Federation Proceedings, 31, 1615.

Ensor, D. M., Edmonson, M. R., and Phillips, J. G. (1972). Fournal of Endocrinology, 53, 59.

Fluckiger, E. (1972). In Prolactin and Carcinogenesis: Fourth Tenovus Workshop, ed. A. R. Boyns, and K. Griffiths. Cardiff, Alpha Omega Alpha.

Frantz, A. G., Kleinberg, D. L., and Noel, G. L. (1972). Recent Progress in Hormone Research, 28, 527.

Friesen, H. G., Fournier, P., and Desjardins, P. (1973). Clinical Obstetrics and Gynecology, 16, No. 3, p.25.

Gant, N. F., et al. (1973). Fournal of Clinical Investigation, 52, 2682.

Genazzani, A. R., Fioretti, P., and Lemarchand-Beraud, Th. (1971). Fournal of Obstetrics and Gynaecology of the British Commonwealth, 78, 117.

of Obstetrics and Gynaecology of the British Commonwealth, 78,
Handler, J. S. (1960). fournal of Clinical Investigation, 39, 1526.

Handler, J. S. (1960). fournal of Clinical Investig

Horrobin, D. F., et al. (1971). Lancet, 2, 352 .
Horrobin, D. F., Manku, M. S., and Burstyn, P. G. (1973), Cardiovascular Research, 7, 585

Jaffe, R. B., et al. (1973). American fournal of Obstetrics and Gynecology, 117,757 .

Kopelman, J. J., and Levitz, M. (1970). American Fournal of Obstetrics and Gynecology, 108, 925.

Laron, Z., et al. (1967). Archives of Disease in Childhood, 42, 24.

Letchworth, A. J., and Chard, T. (1972). Fournal of Obstetrics and Gynaecology of the British Commonwealth, 79, 680 .

Lockett, M. F. (1965). Fournal of Physiology, 181, 192

McNeilly, A. S. (1973). Proceedings of the Royal Society of Medicine, 66, 863.

McNeilly, A. S., and Hagen, C. (1974). Clinical Endocrinology. In press.

Masson, G. M.' (1973). Fournal of Obstetrics and Gynaecology of the British Commonwealth, 80, 206.

Commonwealth, 80, 206.
Mukherjee, K., and Swyer, G. I. M. (1972). Fournal of Obstetrics and Gynaecology of the British Commonwealth, 79, 504 .

Pollak, V. E., and Nettles, J. B. (1960). Medicine, 39, 469.

Seitchik, J. (1953). American fournal of Obstetrics and Gynecology, 65, 981.

Taylor, A. L., et al. (1972). Fournal of Clinical Endocrinology and Metabolism, 34, 395.

Thomas, J. P., and Flynn, T. G. (1964). Clinical Science, 26, 69.

Thomson, A. M., Hytten, F. E., and Billewicz, W. Z. (1967). Fournal of Obstetrics and Gynaecology of the British Commonwealth, 74, 1.

Turkington, R. W. (1972 a). American fournal of Medicine, 53, 389

Turkington, R. W. (1972 b). Archives of Internal Medicine, 130, 349.

Weir, R. J., et al. (1973). Lancet, 1, 291.

Wuttke, W., Gelato, M., and Meites, J. (1971). Endocrinology, 89, 1191.

\title{
Normal Haematological Values: Sex Difference in Neutrophil Count
}

\author{
BARBARA J. BAIN, J. M. ENGLAND
}

British Medical Fournal, 1975, 1, 306-309

\section{Summary}

Blood counts were performed on 100 male and 100 female staff to establish normal ranges for our hospital. Neutro-

\footnotetext{
Department of Haematology and M.R.C. Experimental Haematology Unit, St. Mary's Hospital Medical School, London W2 1PG

BARBARA J. BAIN, M.B., M.R.A.C.P., Lecturer in Haematology

J. M. ENGLAND, M.B., PH.D., Member of M.R.C. Scientific Staff and Honorary Lecturer in Haematology
}

phil counts were found to be on average $0.66 \times 10^{\%} / 1$ $\left(660 / \mathrm{mm}^{3}\right)$ higher in women than in men. Statistically this difference was highly significant and was not due to the fact that many of the women were taking oral contraceptives. The neutrophil counts of the men and women were also on average $0.50 \times 10^{\%} / 1\left(500 / \mathrm{mm}^{3}\right)$ greater in the afternoon than in the morning. A correlation was observed between the neutrophil and the monocyte counts.

\section{Introduction}

Patients with absolute neutrophil counts of less than $2.5 \times 10^{9} / 1$ 
$\left(2500 / \mathrm{mm}^{3}\right)$ are often referred to haematology departments for investigation of neutropenia. It is difficult to interpret such results when the published lower limits of normal vary from as low as $1 \times 10^{9} / 1\left(1000 / \mathrm{mm}^{3}\right)$ to as high as $3 \times 10^{9} / 1\left(3000 / \mathrm{mm}^{3}\right)$ (Osgood et al., 1939; Engelbreth-Holm and Videbaek, 1948; Zarofonetis, 1952; Dacie and Lewis, 1968; Orfanakis et al., 1970; Zacharski et al., 1971). We therefore decided to establish our own normal ranges, performing 500-cell differential counts and using the automated techniques which are now widely used for determining the total white cell count.

\section{Methods}

Venous blood samples were obtained from 100 male and 100 female hospital staff of European origin, aged between 18 and 60 years with median ages of 24 for the men and 25 for the women. Pregnant women, blood donors, and those with coughs, colds, and other minor infections were excluded though three postmenopausal women were included. Venepunctures were performed throughout the year. Altogether 72 men and 70 women were bled between 9.30 and 11.30 a.m., 26 men and 29 women between 2.30 and 4.30 p.m., and two men and one woman after 5 p.m. These times were selected for investigation as they are the times at which blood samples are usually obtained from hospital inpatients and outpatients. Venepunctures were not performed immediately after eating or after any unusual exertion.

The blood samples were anticoagulated with $\mathrm{K}_{2}$ adetic acid, and counted on a Coulter counter, Model S, standardized with 4C Coulter counter cell control. Romanowsky-stained blood films were prepared and differential counts were performed on 500 cells, counting in longitudinal strips. All the counts were made by one observer.

\section{STATISTICAL ANALYSIS}

Total leucocyte count and absolute neutrophil, lymphocyte, and monocyte counts were found to be log normally distributed: a straight line was obtained when the cumulative frequency was plotted on a probability scale against the count on a logarithmic scale (fig. 1) (Healy, 1968). When eosinophil counts were plotted in this manner a curve was obtained with an upward concavity, but by using the method of Kapteyn (Gaddum, 1945) we found that the eosinophil count plus 16 gave a log normal distribution (fig. 1). By calculating the mean $(\mu)$ and the S.D. $(\sigma)$ of the logarithms of the counts the median count $(\exp (\mu))$ and the $95 \%$ confidence limits (exp $(\mu) \pm 1.96 \sigma$ ) for the counts were derived. Sixteen was then subtracted from the median value and the confidence limits calculated for the eosinophil counts.

In many of the subjects the absolute basophil count was apparently zero because no basophils were seen in the 500 -cell differential. It was therefore necessary to use the observed 50th percentile as the median and the 2.5 and 97.5 percentiles as the 95\% confidence limits because no simple transformation would convert the basophil counts to a normal distribution.

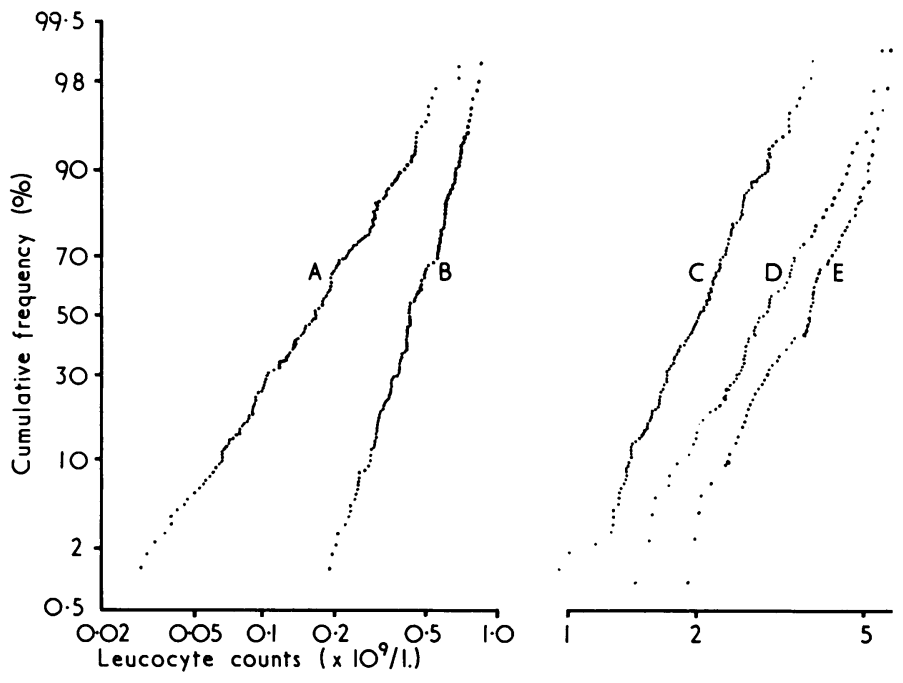

FIG. 1-Leucocyte counts. Cumulative frequencies plotted on probability scale against leucocyte counts on logarithmic scales. $A=$ Eosinophil counts $+16 . \mathrm{B}=$ Monocyte counts. $\mathrm{C}=\mathrm{L}$ ymphocyte counts. $\mathrm{D}=$ Neutrophil counts $+16 . \mathrm{B}=$ Monocyte counts. $\mathrm{C}=$ Lymphocyte counts. $\mathrm{D}=$ Neutrophil counts
in $\mathrm{men}(9.30 \times 11.30 \mathrm{a} . \mathrm{m}.) . \mathrm{E}=$ Neutrophil counts in women $(9.30-11.30 \mathrm{a} . \mathrm{m}$. in men (9.30x11.30 a.m.). $\mathrm{E}=$ Neutrophil counts in women $(9.30-11.30 \mathrm{a} . \mathrm{m}$.

The values of $\mu$ and $\sigma^{2}$ for different groups were compared using Student's $t$ test and the F test respectively. An analysis of variance was used to compare the male and female values in the morning and the afternoon and to compare the morning and afternoon values in women taking or not taking oral contraceptives. For correlation analysis and analysis of variance the logarithms of the counts were used.

We also reanalysed the results of Osgood et al. (1939) to compare with our own. Their total leucocyte count and absolute neutrophil and lymphocyte counts were log normally distributed, and $95 \%$ confidence limits were computed as above. For the absolute monocyte, eosinophil, and basophil counts many zero counts were recorded and it was necessary to use the observed 2.5 and 97.5 percentiles as the $95 \%$ confidence limits.

\section{Results}

NORMAL VALUES

The total leucocyte count was significantly higher in women than in men $(P<0.001)$ due to a highly significant difference in the neutrophil counts $(P<0.0001$; table I). In both sexes the total leucocyte count and the neutrophil count were also significantly higher in the afternoon than in the morning $(\mathrm{P}<0.05)$. The 95\% confidence limits for the neutrophil counts in women and men were, respectively, $1.861 \times 10^{\circ}-6.821 \times$ $10^{9} / 1\left(1861-6821 / \mathrm{mm}^{3}\right)$ and $1.539 \times 10^{9}-5.641 \times 10^{9} / 1(1539$ $\left.5641 / \mathrm{mm}^{3}\right)$ in the morning and in the afternoon $2.137 \times 10^{9}$ $7.836 \times 10^{9} / 1\left(2137-7836 / \mathrm{mm}^{3}\right)$ and $1.775 \times 10^{9}-6.508 \times 10^{9} / 1$ $\left(1775-6508 / \mathrm{mm}^{3}\right)$ (table II). The lower values found for the men imply, for example, that four and a half times as many

TABLE I-Median Leucocyte Counts in Male and Female Hospital Staff in Morning (9.30-11.30 a.m.) and Afternoon (2.30-4.30 p.m.)

\begin{tabular}{|c|c|c|c|c|c|c|c|c|c|c|}
\hline & & & \multicolumn{2}{|c|}{ Men } & \multicolumn{6}{|c|}{ Women } \\
\hline & & & \multirow[b]{2}{*}{ Morning } & \multirow[b]{2}{*}{ Afternoon } & \multicolumn{3}{|c|}{ Morning } & \multicolumn{3}{|c|}{ Afternoon } \\
\hline & & & & & All Women & $\begin{array}{c}\text { Women on } \\
\text { Oral } \\
\text { Contraceptives }\end{array}$ & $\begin{array}{l}\text { Women Not on } \\
\text { Oral } \\
\text { Contraceptives }\end{array}$ & All Women & $\begin{array}{c}\text { Women on } \\
\text { Oral } \\
\text { Contraceptives }\end{array}$ & $\begin{array}{c}\text { Women Not on } \\
\text { Oral } \\
\text { Contraceptives }\end{array}$ \\
\hline $\begin{array}{l}\text { Total leucocytes }\left(\times 10^{\circ} / 1\right) \\
\text { Neutrophils }\left(\times 10^{\circ} / 1\right) \\
\text { Lymphocytes }\left(\times 10^{\circ} / 1\right) \\
\text { Monocytes }\left(\times 10^{\circ} / 1\right) \\
\text { Eosinophils }\left(\times 10^{\circ}\right) \\
\text { Basophils }\left(\times 10^{\circ} / 1\right) \ldots\end{array}$ & $\begin{array}{l}\because \\
\because \\
\because \\
\therefore\end{array}$ & $\begin{array}{l}. \\
\because \\
\because \\
\cdots \\
\cdots\end{array}$ & $\begin{array}{l}5.665 \\
2.952 \\
1.956 \\
0.427 \\
0.150 \\
0.035\end{array}$ & $\begin{array}{l}6.049 \\
3.400 \\
1.868 \\
0.434 \\
0.156 \\
0.040\end{array}$ & $\begin{array}{l}6 \cdot 237 \\
3.563 \\
1.969 \\
0.416 \\
0.122 \\
0.025\end{array}$ & $\begin{array}{l}6 \cdot 365 \\
3.668 \\
2 \cdot 001 \\
0 \cdot 390 \\
0 \cdot 130 \\
0.026\end{array}$ & $\begin{array}{l}6.215 \\
3.597 \\
1.918 \\
0.424 \\
0.126 \\
0.023\end{array}$ & $\begin{array}{l}7 \cdot 231 \\
4 \cdot 093 \\
2 \cdot 283 \\
0 \cdot 481 \\
0 \cdot 151 \\
0.048\end{array}$ & $\begin{array}{l}7 \cdot 260 \\
4 \cdot 122 \\
2 \cdot 324 \\
0.461 \\
0 \cdot 152 \\
0.048\end{array}$ & $\begin{array}{l}7 \cdot 380 \\
4 \cdot 311 \\
2 \cdot 199 \\
0.497 \\
0 \cdot 151 \\
0.046\end{array}$ \\
\hline
\end{tabular}

Conversion: SI to Traditional Units-W.B.C.: $1 \times 10^{\circ} / 1=1000 / \mathrm{mm}^{3}$. 
TABLE II-Normal Values in 100 Male and 100 Female Hospital Staff. 95\% Confidence Limits. Values for Both Sexes Combined are given in Parentheses where Appropriate

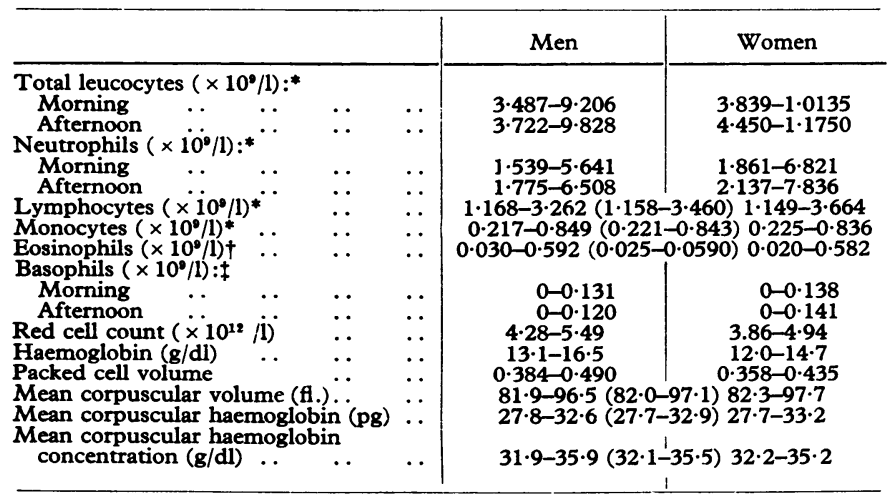

*Lognormal distribution.

†Lognormal distribution of count plus 16

Conversion: SI to Traditional Units W.B.C.: $1 \times 10 \%=1000 / \mathrm{mm}^{3} . t$

men as women have neutrophil counts below $2 \times 10^{\%} / 1$ $\left(2000 / \mathrm{mm}^{3}\right)$ in the morning; similarly, over twice as many women have counts above $5 \times 10^{\%} / 1\left(5000 / \mathrm{mm}^{3}\right)$ (fig. 2).

No significant differences were found between the absolute

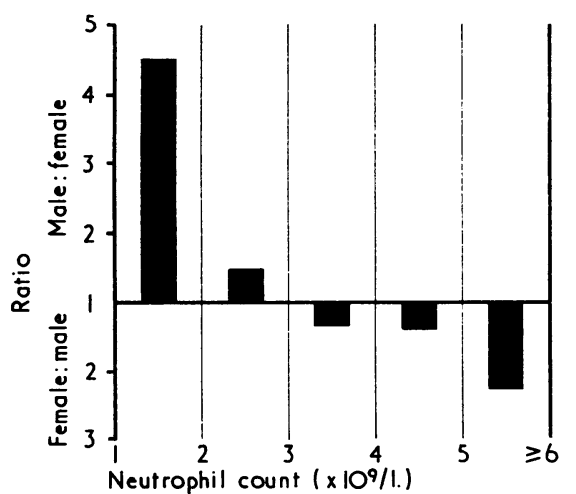

FIG. 2-Neutrophil counts. Relative frequency with which various counts were observed in men and women. When counts were commoner in men than women the results are presented as male : female ratio and when reverse was true results are presented as female : male ratio. All values are reverse was true res

Conversion: SI to Traditional Units-Neutrophils: $1 \times 10^{9} / 1=1000 \mathrm{~mm}^{3}$.

lymphocyte, monocyte, and eosinophil counts of the men and the women nor were there any differences between the morning and the afternoon (P>0.05; table I). The women, however, had higher basophil counts in the afternoon than in the morning (table I)-for example, $21 \%$ of women had counts above $0.06 \times 10^{\circ} / 1\left(60 / \mathrm{mm}^{3}\right)$ in the morning and $45 \%$ had similar counts in the afternoon ( $P<0.05, \chi^{2}$ test). The $95 \%$ confidence limits for these counts are given in table II.

\section{ORAL CONTRACEPTIVES}

Since many of the women were taking oral contraceptives, which have been reported to raise the neutrophil count (Pincus, 1965), we decided to compare the haematological values of those premenopausal women taking oral contraceptives with the values of those who were not. No significant differences were observed between the two groups for the neutrophil count or for any other measurement either in the morning or in the afternoon $(P>0.05)$ though in both groups the neutrophil counts were higher in the afternoon (table I).

The neutrophil counts of the women taking oral contraceptives were significantly higher than those of the men $(P<0.005)$, as were the counts of the women not taking oral contraceptives $(\mathbf{P}<0.001)$.

\section{CORRELATION BETWEEN NEUTROPHIL AND MONOCYTE COUNTS}

In both women and men there were significant correlations between the neutrophil and the monocyte counts in both the morning and the afternoon (women in the morning $r=0.431$, $P<0.001$; women in the afternoon $r=0.470, P<0.05$; men in the morning $r=0.274, P<0.05$; men in the afternoon $r=0.628$, $P<0.001)$. This correlation, while being of great theoretical interest, explains only a small part of the observed variation in the monocyte count. No statistically significant correlations were found between the absolute counts of any other two white cell types.

\section{Discussion}

We observed a higher total leucocyte count in women than in men due to a highly significant difference in the absolute neutrophil count. Several workers have previously investigated leucocyte counts in men and women. One of the earliest studies was that of Osgood et al. (1939), who observed that women had a slightly higher neutrophil count than men but that the observed difference was not statistically significant (table III). Since then Heine et al. (1960) have reported that women have higher neutrophil counts than men, but Allan and Alexander (1968) claimed that women had significantly lower counts. Other workers have not related their results to the sex of their subjects or have studied subjects predominantly of one sex (Turner, 1956; Wintrobe, 1967; Orfanakis et al., 1970).

There are several possible explanations for the difference in neutrophil counts between men and women. MacKinnon (1953) and Morley (1966) have suggested that there is a cyclical variation of the neutrophil count with the menstrual cycle. These findings imply that the level of oestrogen or progestogen may be an important factor in regulating the neutrophil count. A rise of the neutrophil count is also associated with increasing hormone levels in pregnancy. Furthermore, oestrogen levels correlate with the neutrophil count in women treated with follicle-stimulating hormone and chorionic gonadotrophin (Cruickshank et al., 1970), and oestrogen seems to enhance granulocyte proliferation in vitro (Reisner, 1966). Our small number of postmenopausal women did not differ from the rest of the female group but studies of larger groups of postmenopausal women have shown a postmenopausal fall in the neutrophil count (Allan and Alexander, 1968; Cruickshank and Alexander, 1970).

The difference in neutrophil counts between the men and the women was unrelated to oral contraceptive therapy; those

TABLE III-Normal Values for Leucocytes: 95\% Confidence Limits reported in Previous Studies

\begin{tabular}{|c|c|c|c|c|c|c|c|c|}
\hline & & No. of Subjects & $\begin{array}{c}\text { Total Leucocytes } \\
\left(\times 10^{\circ} / 1\right)\end{array}$ & $\begin{array}{c}\text { Neutrophils } \\
\left(\times 10^{\circ} / 1\right)\end{array}$ & $\underset{\left(\times 10^{\circ} / 1\right)}{\text { Lymphocytes }}$ & $\begin{array}{c}\text { Monocytes } \\
\left(\times 10^{\circ} / 1\right)\end{array}$ & $\underset{\left(\times 10^{\circ} / 1\right)}{\text { Eosinophils }}$ & $\begin{array}{l}\text { Basophils } \\
\left(\times 10^{\circ} / 1\right)\end{array}$ \\
\hline $\begin{array}{l}\text { Osgood et al., 1939* .. } \\
\text { Blackburn et al., 1947 } \\
\text { Orfanakis et al., 1970 } \\
\text { Zacharski et al., } 1971\end{array}$ & $\begin{array}{ll}\ldots & \{ \\
\cdots & \cdots \\
\cdots & \cdots\end{array}$ & $\begin{array}{c}198 \mathrm{M} . \\
71 \mathrm{~F} . \\
642 \mathrm{M} . \\
204 \mathrm{M} ., 22 \mathrm{~F} . \\
292 \mathrm{M} ., 215 \mathrm{~F} .\end{array}$ & $\begin{array}{l}4.637-1.0965 \\
4.509-1 \cdot 1666 \\
4 \cdot 148-12 \cdot 130 \\
4.550-10 \cdot 100 \\
4 \cdot 100-10.900\end{array}$ & $\begin{array}{l}1.913-7.356 \\
1.945-8.239 \\
1.815-8.056 \\
2.050-6.800 \\
2.266-7.676\end{array}$ & $\begin{array}{r}1 \cdot 300-5 \cdot 169 \\
1 \cdot 308-4 \cdot 818 \\
1 \cdot 500-4 \cdot 000 \\
0 \cdot 832-3 \cdot 140\end{array}$ & $\begin{array}{r}0-0.870 \\
0-0.852 \\
0.220-0.950 \\
0.123-0.804\end{array}$ & $\begin{array}{r}0-0.600 \\
0-0.469 \\
0.030-0.860 \\
0-0.492\end{array}$ & $\begin{array}{l}0-0.190 \\
0-0.272 \\
0-0.160 \\
0-0.156\end{array}$ \\
\hline
\end{tabular}

*See Statistical Analysis.

Conversion: SI to Traditional Units-W.B.C.: $1 \times 10^{\circ} / 1=1000 / \mathrm{mm}^{3}$. 
women who were taking oral contraceptives did not have a higher neutrophil count than those who were not and both groups had counts which were significantly higher than those of the men. Our observations contrast with those of Pincus (1965), who showed that oral contraceptives raised the neutrophil count. His subjects were taking preparations with $75-$ $150 \mu \mathrm{g}$ of oestrogen, however, whereas the oral contraceptives taken by our subjects contained $30-50 \mu \mathrm{g}$ of oestrogen and also usually had a lower progestogen content.

Our results also confirm earlier observations that the neutrophil count rises in the afternoon (Garrey and Bryan, 1935; Kennon et al., 1937). We therefore suggest that it is important to consider both the sex and the time of day when deciding whether a neutrophil count is lower than normal. The lower limit of normal which is widely used is $2.5 \times 10^{9}$ neutrophils/1 $\left(2500 / \mathrm{mm}^{3}\right)$. Our results show that this value is too high for either sex, particularly in the morning, when-for example, $31 \%$ of our normal men had counts below this level.

Variation of the neutrophil count may also occur on a racial basis. For example, Shaper and Lewis (1971) have observed a mean neutrophil count of $1.96 \times 10^{9} / 1\left(1960 / \mathrm{mm}^{3}\right)$ in 250 male African blood donors. This value is lower than the mean value which we found in this study of Caucasians of European origin.

The values we have observed for the lymphocyte, monocyte, eosinophil, and basophil counts are similar to those in previously published series (table III), and we have also confirmed earlier observations that the basophil count rises in the afternoon (Finch, 1972). The correlation which we have noted between the monocyte and the neutrophil count was previously reported by Twomey et al. (1973). This interesting correlation is consistent with the suggestions that neutrophils and monocytes either have a common precursor or have similar regulatory mechanisms.
We thank Professor P. L. Mollison and Dr. S. N. Wickramasinghe for their helpful suggestions and our colleagues who donated their blood samples.

\section{References}

Allan, R. N., and Alexander, M. K. (1968). Journal of Clinical Pathology, 21,691 .

Blackburn, C. R. B. (1947). Medical fournal of Australia, 1, 525.

Cruickshank, J. M., and Alexander, M. K. (1970). British fournal of Haematology, 18, 541 .

Cruickshank, J. M., et al. (1970). Fournal of Obstetrics and Gynaecology of the British Commonwealth, 77, 634.

Dacie, J. V., and Lewis, S. M. (1968). Practical Haematology, 4th edn., p. 13. London, Churchill.

Engelbreth-Holm, J., and Videbaek, A. A. (1948). Blood, 3, 612

Finch, S. C. (1972). In Hematology, ed W. J. Williams, et al., p. 645. New York, McGraw-Hill.

Gaddum, J. H. (1945). Nature, 156, 463.

Garrey, W. E., and Bryan, W. R. (1935). Physiological Review, 15, 597. Healy, M. J. R. (1968). British Medical Bulletin, 24, 210.

Heine, H., Heine, K., and Schmidt, H. (1960). Acta Biologica et Medica Germanica, 5, 221.

Kennon, B. R., Shipp, M. E., and Hetherington, D. C. (1937). American fournal of Physiology, 118, 690

MacKinnon, J. L. (1953). Fournal of Obstetrics and Gynaecology of the British Empire, 60, 721 .

Morley, A. A. (1966). Lancet, 2, 1220.

Orfanakis, N. G., et al. (1970). American fournal of Clinical Pathology, 53, 647.

Osgood, E. E., et al. (1939). Archives of Internal Medicine, 64, 105.

Pincus, G. (1965). The Control of Fertility, p. 277. New York, Academic Press.

Reisner, E. H. (1966). Blood, 27, 460

Shaper, A. G., and Lewis, P. (1971). Lancet, 2, 1021

Turner, F. M. (1956). British fournal of Industrial Medicine, 13, 277

Twomey, J. J., Douglass, C. C., and Sharkey, O. (1973). Blood, 41, 187.

Wintrobe, M. M. (1967). Clinical Hematology, p. 260. London, Henry Kimpton.

Zacharski, L. R., Elveback, L. R., and Linman, J. W. (1971). American fournal of Clinical Pathology, 56, 148.

Zarofonetis, C. J. D. (1952). In Approved Laboratory Technic, ed. J. A. Kolmer, E. H. Spaulding, and H. W. Robinson, p. 103. London, H. K. Lewis and Co. Ltd.

\title{
Postoperative Management after Thymectomy
}

\author{
A. B. LOACH, A. C. YOUNG, J. M. K. SPALDING, A. CRAMPTON SMITH
}

British Medical fournal, 1975, 1, 309-312

\section{Summary}

This paper reports a retrospective study of the preoperative and postoperative management of 28 patients who underwent thymectomy between 1956 and 1973 . Patients who received postoperative artificial ventilation were compared with the group who did not with respect to sex, age, severity of disease, preoperative vital capacity, and thymic histology. Evidence is presented that postoperative artificial ventilation is required when the preoperative vital capacity with the patient on optimum anticholinesterase treatment is less than 2 litres. Additional features associated with a probable need for

Radcliffe Infirmary, Oxford OX2 6HE

A. B. LOACH, M.B., F.F.A. R.C.S., Senior Registrar, Nuffield Department of Anaesthetics

J. M. K. SPALDING, D.M., F.R.C.P., Consultant Neurologist

Churchill Hospital, Headington, Oxford

A. C. YOUNG, M.B., M.R.C.P., Senior Registrar, Department of Neurology

University of Oxford

A. CRAMPTON SMITH, M.B., F.F.A. R.c.S., Nuffield Professor of Anaesthetics artificial ventilation were the presence of a thymoma, bulbar symptoms, especially dysphagia, and age over 50 years. These should be taken into account in any patient whose vital capacity is close to the critical level of 2 litres. When postoperative ventilation was required it was usually necessary for 12 days or more, and tracheostomy should therefore be done at or before thymectomy. Most patients in this series received the same dose of anticholinesterases after operation as before it and no evidence was found of a sudden decrease in requirements for anticholinesterase therapy. Two patients did not, and in them a myasthenic crisis was precipitated. We propose that the preoperative drug regimen can be continued in the immediate postthymectomy period, allowing selection of patients for tracheostomy and artificial ventilation primarily on the basis of the preoperative vital capacity.

\section{Introduction}

Though there is general agreement on the value of thymectomy in myasthenia gravis there is controversy about the immediate postoperative management. A postoperative mortality of $10 \%$ in the earlier years led to the adoption of regimens such as that of Osserman and Genkins (1971), who advocated routine 